\title{
The Impact of Board Members Involvement on Return on Equity (ROE)
}

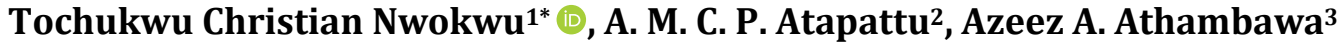 \\ ${ }^{1}$ Post Graduate \& Mid-Career Development Unit, University of Colombo, Colombo, Sri Lanka \\ ${ }^{2}$ Department of Business Economics, University of Colombo, Colombo, Sri Lanka \\ ${ }^{3}$ Department of Finance, University of Colombo, Colombo, Sri Lanka \\ Email: ^toojahchris@gmail.com, cpatapattu@gmail.com, aazeez72@dfn.cmb.ac.lk
}

How to cite this paper: Nwokwu, T.C., Atapattu, A.M.C.P. and Azeez, A.A. (2019) The Impact of Board Members Involvement on Return on Equity (ROE). Modern Economy, 10, 1334-1347. https://doi.org/10.4236/me.2019.104090

Received: February 26, 2019

Accepted: April 22, 2019

Published: April 25, 2019

Copyright (c) 2019 by author(s) and Scientific Research Publishing Inc. This work is licensed under the Creative Commons Attribution International License (CC BY 4.0).

http://creativecommons.org/licenses/by/4.0/

(c) (i) Open Access

\begin{abstract}
From a developing economy, the impact of board members involvement on return on equity has been analyzed. The current study uses the correlation and regression models to analyze publicly available data of which the sample firms were taken from 11 sectors that are quoted in the Nigerian Stock Exchange for one financial year. Several diagnostic tests have been applied to justify the validity of the results. The empirical investigations reveal that two of the independent variables have significant impact on return on equity. This research paper in its originality is the first of its kind in a developing economy like Nigeria.
\end{abstract}

\section{Keywords}

Corporate Governance, Board Shareholdings, Board Independence, Financial Performance Indicator, Board Size, Return on Equity, Board Experience

\section{Introduction}

Corporate governance is very integral to the success of firms because it acts as their road maps towards the protection of their shareholders' and stakeholders' interests as well as carrying out other activities of the firm. It is worthy of note that there are certain factors that enhance the involvement of board members towards achieving their ultimate goal which is corporate performance. Some of these factors are: the level of skills possessed by each board members that are needed by the organisation [1], the willingness on the part of the board of directors to work together as a team and engage themselves on the issues that concern the company, and above all, there should be a high level of trust existing among board members, as well as great trust existing between the stakeholders and the 
board of directors [2]-[7]. Shareholder activists have long argued that the roles of chief executive officer (CEO) and chairman of the board should be separated to contain CEO dominance over other board members [8]. [9] made this point clear by saying that CEO duality has no influence on firm performance. [10] supported this argument by saying that the chairman as the head of the board can play a central role in ensuring the effective governance of the enterprise and is responsible for the board's effective functioning. They went further to say that the separation of the roles of the chairman and the CEO is proposed as a method of ensuring an appropriate balance of power and increasing accountability and the capacity of the board for independent decision making. While on the other hand, other researchers are of the opposite opinion. Moreover, the CEO and board chairperson should be different people in order to clearly separate operational from control responsibilities [11].

However, the importance of corporate governance practices is evidenced in the way companies are directed and controlled by their organized corporate structures and processes, thereby helping them to achieve high performance. Having an appropriate mix of directors in the board is important in achieving firm performance [12]. Other researchers focused on board involvement on earnings per share and price earning [12] [13] [14], while this research aims at ascertaining the impact of board involvement on return on equity. Return on equity is a proxy for firm performance. This is why [15] argues that there is no universal applicability of corporate governance due to varying contextual factors pertaining to research settings, such as national diversity, status of economies, political stability, institutional constraints, cultural backgrounds, etc.

This research intends to make contributions to the corporate world and to the corporate governance research at the end of this study. Such contributions will make this study very useful to policymakers, management practitioners, as well as adding to the theoretical and existing literatures on corporate governance. The fact that this work is first of its kind in a country like Nigeria makes it unique. However, the empirical findings will be discussed in Section 4 of this research.

\section{Plan of Study}

This article is organized into four (4) sections. Section one discusses the general background or overview of the study as well as the objectives and significance of the study. Section two reviews different literatures both old and new written by several researchers. Furthermore, conceptual framework and hypothesis were developed in this section. Section three talks about the research methodology i.e. techniques of data collections and analysis. Section four is all about discussions and conclusion.

\section{Literature Review}

[2] argued that the top-level decision control device within both large and small organizations is board of directors that deals with the agency problem caused by the separation of ownership and control. In order to solve this agency problem, 
boards are evolving towards a more collaborative role with management. This is evidenced when the board includes both directors who are managers of the firm (inside directors) and those who are not full-time employees of the firm (outside directors). Directors are typically grouped into two categories: insiders and outsiders. Inside directors are current or formal employees of a company. They typically hold or have held high-level executive positions and thus offer the board an in-depth working knowledge of the organization [16]. In Nigeria, as in many former colonies, the government of the newly independent country perceived a need for greater local control over productive resources, which during the colonial period were largely dominated by foreign owners [17]. The changed in political and economic in South Africa result to major reformed in corporate governance legislation which focused on Companies Act 1973 [18]. [19] explained that the financial regulatory system in South Africa comprises three main components including the regulation of financial instruments, regulation of the market in which this instrument is being traded and the regulation of those that participated in the market.

The independent variables used in this work and how they are measured are as follows: Board meeting frequency is measured as the total number of board meetings held in a financial year [8]. Frequent board meetings are one way the board responds to tough years of operation [8]. Hence, the researchers of this work introduced a new independent variable known as frequency of board meetings because they believe that frequency of board meetings are beneficial to both the shareholders and the stakeholders. Both, resource dependence and agency theories suggest board members to have unbiased boardroom meetings with reasonable number of frequency of board meetings in order to minimize information asymmetry as well as to reduce external dependences. Hence, the researchers propose the following hypothesis:

H1. Board meeting frequency is not associated with return on equity.

Board Independent committee is measured as the total number of standing board committees [8]. When an organization set up a distinct strategic planning committee of the board, more formality occurred in the development of long-range goals and action plans, as well as in the monitoring of results [20]. Also the existence of independent board committees helps to achieve smaller goals which are summed up to be the overall goal of the company. These goals were delegated by the corporate board among the available independent board committees [8]. Further greater independence and authority needs to be granted to oversight committees within the firm. In particular, the roles and functions of the remuneration and audit committees need to be strengthened. This will serve to facilitate both transparency and accountability within firm [21]. Companies are also encouraged to nominate directors with expertise and experience in their board committees in order to improve the committees' effectiveness [22].

In order to encourage transparency and accountability on corporate matters, the researchers propose the following hypothesis: 
H2. Board Independent committees are not associated with return on equity. Board shareholding is measured as the total number of shares held by the directors of a firm divided by the number of outstanding shares [23]. Directors' shareholdings will encourage the board to protect the interest of shareholders by monitoring the managers [24]. Therefore, the researcher is adopting the variable directors' shareholding.

[15] argued that performance is attributed to board. Carver is right because it's the board that manages the activities of the firm, in order to ensure that the interests of shareholders are protected and to see that the company progresses. Combining the points of [24] and [15], it simply means that where there is directors' shareholding, the board will be motivated to manage the activities of the company as well as ensuring that the interests of shareholders are protected. The boards of directors and its monitoring role have received increasing attention from researchers [2]. It should be noted that the board of directors play a central role in corporate governance [25]; such focal role is the monitoring of management activities.

The above points lead to the following hypothesis that will be tested in this research:

H3. Board Shareholding is not associated with return on equity.

Board members' relatives are measured as dummy variable taking the value of 1 if board members have relatives on the same board, otherwise 0 [23], [23] observed that more than one family member in a board will result to adverse effect. In addition to Ehikioya's point of view, the researchers of this work is of the opinion that if more than one family member are in the same board meeting, and they are not at peace with each other in the family, they might bring in the family grievances into the board meeting, and this will cause disagreement and disunity among board members. On the other hand, they can be at peace with each other, and they might use the unity existing among them to satisfy their greed by embezzling the company's money.

From the above examples illustrated, it can be vividly seen that both scenarios do not favour the company, and as such will adversely affect the corporate performance of the firm. On the other hand, is still possible that the unity of the family members can be used to increase the corporate performance of the firm. On this note, the researchers propose the following hypothesis:

H4. Board Members' Relatives is not associated with return on equity.

Board size is measured as the total number of board members [23]. In firms with larger boards, board meeting time seems to be partly wasted due to inefficient board sizes [8]. In addition, larger boards are probably less effective in communicating and reaching consensus and, hence, more susceptible to manipulation by the CEO. [26] [27] [28], are of same opinion that board size has negative impact on board's decision and firm performance. However, the diversity within the board when there are too many members could create conflicts leading to distrust, hostility, and less motivation [26].

A Board that is large has the tendency of having members who will not ade- 
quately contribute effectively to corporate performance. Whereas, [9] supported the claim that small board size has influence on firm performance. However, resource dependency theory sees board members as essential resources. Therefore, this work proposes the following hypothesis:

H5. Board's size is not associated with return on equity.

These variables have being used by different researchers in various ways to ascertain the need for the involvement of board members in firms [8] [12] [13] [26] [29]. Firm age and firm size helps to reveal the growth and maturity of the organization [23] [30]. Firm's age is measured as the number of years since its establishment [23]; firm's size is the total assets of the firm, measured as the natural logarithm of total assets [23] [28]; board expertise is measured as the number of board members with degree/qualification [23]; firm's leverage is measured as the total liabilities divided by total assets [23] [28].

The researchers make use of Return on Equity (ROE) as the measure of performance. Below is how it will be used to measure firm performance:

ROE-It means Return on Equity. It is one of the key financial performance indicators. The researchers observed that this measure is also used by other researchers to measure firm performance. It is measured as net profit after tax divided by total equity [23] [28] [31]. It should be noted that return on equity is a proxy for firm performance. In other words, it can be used interchangeably. However, return on equity is the dependent variable.

In this section, the researchers develop a conceptual framework. The researchers of this work observed that from previous literatures, some researchers used written sentences to explain their conceptual frameworks. While on the other hand, some researchers used diagram to represent their conceptual frameworks.

For the purpose of this study, the researchers used diagram to explain the conceptual framework, which is the diagrammatic representation of the independent variables, and the dependent variable and how they are positioned to show the relationship between the independent variables and the dependent variable. Below is the research framework of this study:

The data sources (Figure 1) and data are valid and reliable because they were gotten from 2011 annual reports of firms listed in the Nigeria Stock Exchange. The sample size is 69 .

\section{Method-The Multiple Regression Model}

Multiple regression model given by Equation (1) has been applied to examine the effect of board involvement on ROE.

$$
\begin{aligned}
\mathrm{ROE}= & \Upsilon_{0}+\Upsilon_{1} \mathrm{BMF}+\Upsilon_{2} \mathrm{BIC}+\Upsilon_{3} \mathrm{BSH}+\Upsilon_{4} \mathrm{BMR} \\
& +\Upsilon_{5} \mathrm{BSI}+\Upsilon_{6} \mathrm{FAG} \Upsilon_{7} \mathrm{BEX}+\Upsilon_{8} \mathrm{FLEV}+\mu
\end{aligned}
$$

where ROE is Return on Equity, BMF is Board Meeting Frequency, BIC is Board Independent Committees, BSH is Board Shareholdings, BMR is Board Members Relatives, BSI is Board Size, FAG is Firm Age, BEX is Board Expertise, and FLEV is Firm Leverage. 


\subsection{Descriptive Statistics}

Table 1 is the descriptive statistics for ROE.

Table 1 presents a summary of the descriptive statistics of the explanatory variables and response variable. From the descriptive statistics, the mean and standard deviation of board meetings frequency are respectively 5.28 and 1.86 . The implication is that on the average, the firms had frequency of board meetings 5 times in the financial year. Board independent committees have a mean of

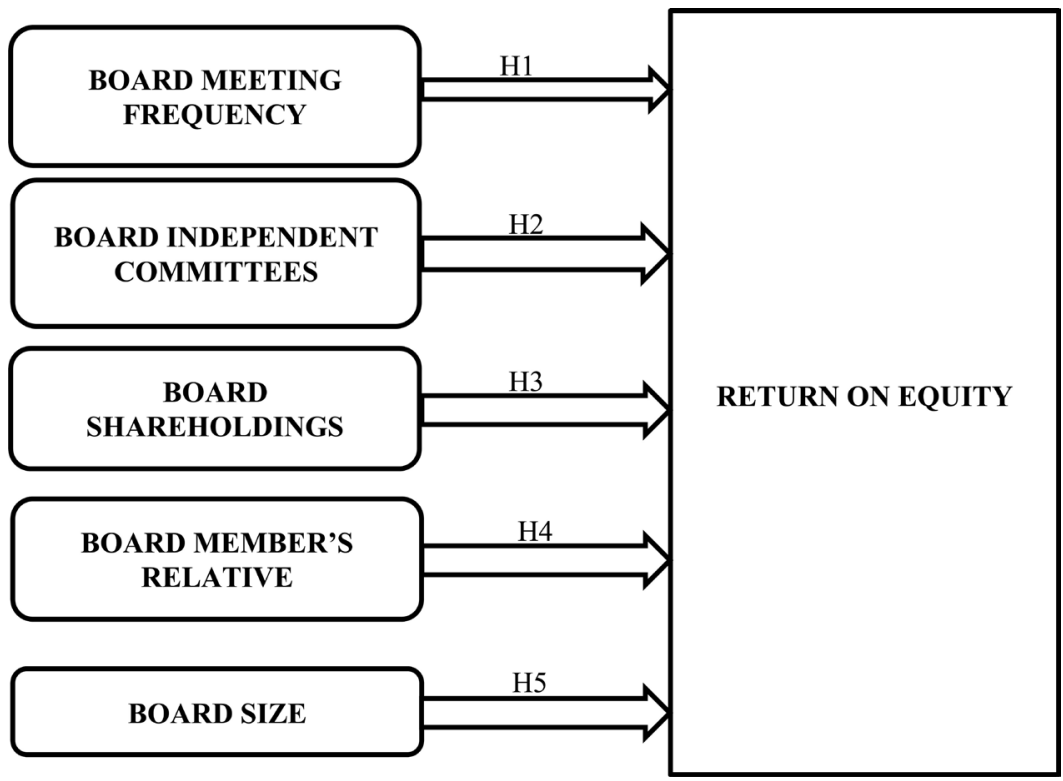

Source: Author's Diagram.

Figure 1. Research framework.

Table 1. Descriptive statistics of board involvement and corporate performance.

\begin{tabular}{|c|c|c|c|c|c|c|c|c|c|}
\hline & $\mathrm{BMF}$ & $\mathrm{BIC}$ & BSH & BMR & BSI & FAG & BEX & FLEV & ROE \\
\hline Mean & 5.289855 & 3.811594 & 0.159135 & 0.173913 & 9.811594 & 36.55072 & 9.739130 & 0.554220 & 0.065458 \\
\hline Median & 5.000000 & 4.000000 & 0.061600 & 0.000000 & 9.000000 & 32.00000 & 9.000000 & 0.520500 & 0.077600 \\
\hline Maximum & 12.00000 & 6.000000 & 0.893500 & 1.000000 & 18.00000 & 117.0000 & 18.00000 & 1.521300 & 0.715500 \\
\hline Minimum & 2.000000 & 1.000000 & 0.000300 & 0.000000 & 5.000000 & 5.000000 & 5.000000 & 0.063400 & -1.6612 \\
\hline Std. Dev. & 1.863752 & 1.101808 & 0.206456 & 0.381812 & 2.936962 & 23.00865 & 2.893462 & 0.275184 & 0.328690 \\
\hline Skewness & 1.384200 & -0.353064 & 1.457124 & 1.720618 & 0.930323 & 1.107770 & 1.003356 & 0.497798 & -2.77352 \\
\hline Kurtosis & 4.982928 & 2.990061 & 4.422937 & 3.960526 & 3.322628 & 4.588135 & 3.558992 & 3.550318 & 14.89433 \\
\hline Jarque-Bera & 33.33862 & 1.433810 & 30.23809 & 36.69856 & 10.25251 & 21.36352 & 12.47566 & 3.720427 & 495.2035 \\
\hline Probability & 0.000000 & 0.488261 & 0.000000 & 0.000000 & 0.005939 & 0.000023 & 0.001954 & 0.155639 & 0.000000 \\
\hline Sum & 365.0000 & 263.0000 & 10.98030 & 12.00000 & 677.0000 & 2522.000 & 672.0000 & 38.24120 & 4.516600 \\
\hline Sum Sq. Dev. & 236.2029 & 82.55072 & 2.898444 & 9.913043 & 586.5507 & 35999.07 & 569.3043 & 5.149395 & 7.346513 \\
\hline Observations & 69 & 69 & 69 & 69 & 69 & 69 & 69 & 69 & 69 \\
\hline
\end{tabular}

Source: Author's Statistical Output. 
3.81 and standard deviation of 1.10. This means that on the average, the board independent committees are 3. Board's shareholdings record a mean and standard deviation of 0.15 and 0.20 respectively. This implies that on the average, the board of directors had $15 \%$ shareholdings in the firm. The analysis revealed the mean and standard deviation of board members relative on board as 0.17 and 0.38 respectively. Statistic records 9.81 and 2.93 as the respective mean and standard deviation for board size. This means that, on the average, there are 9 board members on the board. The respective values 9.73 and 2.89 are the mean and standard deviation for board expertise. This implies that, on the average, there are 9 board members on the board who are qualified and have experience. Respectively 36.55 and 23.00 are the mean and standard deviation for firm age. This means that on the average the firm age is 36 years. Finally, the firm leverage has a record of 0.55 and 0.27 as its mean and standard deviation respectively. The implication of this result is that on the average, the firms have more debt than assets. From the descriptive statistics, the mean and standard deviation of ROE are 0.06 and 0.32 respectively. This means that on the average, the return on asset is \#0.06k.

\subsection{Correlation Analysis}

According to the correlation analysis (Table 2), probabilities of the association between board meeting frequency and board independent committees, board meeting frequency and board expertise, board independent committees and board size, board independent committees and board expertise, board size and board expertise, board size and firm leverage, board expertise and firm leverage are all significant at $1 \%$ level, while Board shareholding and firm age, Board shareholding and return on equity are having significant association at $5 \%$ level.

Board shareholding is the only independent variable whose hypothesis was rejected because it correlates with return on equity, while board meeting frequency, board independent committees, board members relatives on board and

Table 2. Correlation analysis.

\begin{tabular}{cccccccccc}
\hline $\begin{array}{c}\text { Correlation } \\
\text { Probability }\end{array}$ & BMF & BIC & BSH & BMR & BSI & FAG & BEX & FLEV ROE \\
\hline BMF & 1.00 & & & & & & & & \\
BIC & $(0.31)^{* *}$ & 1.00 & & & & & & & \\
BSH & 0.03 & -0.19 & 1.00 & & & & & & \\
BMR & -0.01 & -0.03 & 0.03 & 1.00 & & & & & \\
BSI & $(0.43)^{* *}$ & $(0.34)^{* *}$ & -0.20 & -0.05 & 1.00 & & & & \\
FAG & 0.12 & 0.08 & $(-0.26)^{*}$ & -0.23 & 0.00 & 1.00 & & & \\
BEX & $(0.34)^{* *}$ & $(0.32)^{* *}$ & -0.19 & -0.04 & $(0.98)^{* *}$ & -0.07 & 1.00 & & \\
FLEV & 0.17 & 0.17 & -0.20 & 0.03 & $(0.36)^{* *}$ & 0.20 & $(0.34)^{* *}$ & 1.00 & \\
ROE & -0.11 & -0.03 & $(-0.25)^{*}$ & 0.04 & -0.16 & -0.08 & -0.12 & -0.17 & 1.00 \\
\hline
\end{tabular}

Source: Author's Statistical Output. ${ }^{*}$ and ${ }^{*}$ indicate the significance levels at 0.01 and 0.05 respectively. 
board size are the independent variables whose hypotheses fails to be rejected because they are not correlated with return on equity. Effect of board involvement has been analyzed by applying multiple regression models and diagnostics results have been provided.

Breusch-Godfrey Serial Correlation LM Test is having prob (Table 3). of observed $\mathrm{R}$ square as 0.20 . This is insignificant at $5 \%$ and it indicates that residuals are not correlated with each other. This means that residuals are independent. Hence, results are valid.

The observed R-square of Breusch-Pagan-Godfrey Heteroskedasticity test is insignificant because 0.23 is the probability (Table 4). Therefore, variance of residual is constant. It means that residuals are having homoscedasticity. This also implies that the model is appropriate.

CUSUM test was used to test the parameters stabilization with respect to 5\% level of significance. From the above Figure 2, the curve behaves between the

Table 3. Breusch-Godfrey Serial Correlation LM Test.

\begin{tabular}{cccc}
\hline F-statistic & 1.374887 & Prob. F $(2,57)$ & 0.2611 \\
Obs ${ }^{*}$ R-squared & 3.175483 & Prob. Chi-Square (2) & 0.2044 \\
\hline
\end{tabular}

Source: Author's Statistical Output.

Table 4. Heteroskedasticity Test: Breusch-Pagan-Godfrey.

\begin{tabular}{cccc}
\hline F-statistic & 1.337443 & Prob. F $(9,59)$ & 0.2378 \\
Obs ${ }^{*}$ R-squared & 11.69182 & Prob. Chi-Square (9) & 0.2312 \\
Scaled explained SS & 16.33892 & Prob. Chi-Square (9) & 0.0601 \\
\hline
\end{tabular}

Source: Author's Statistical Output.

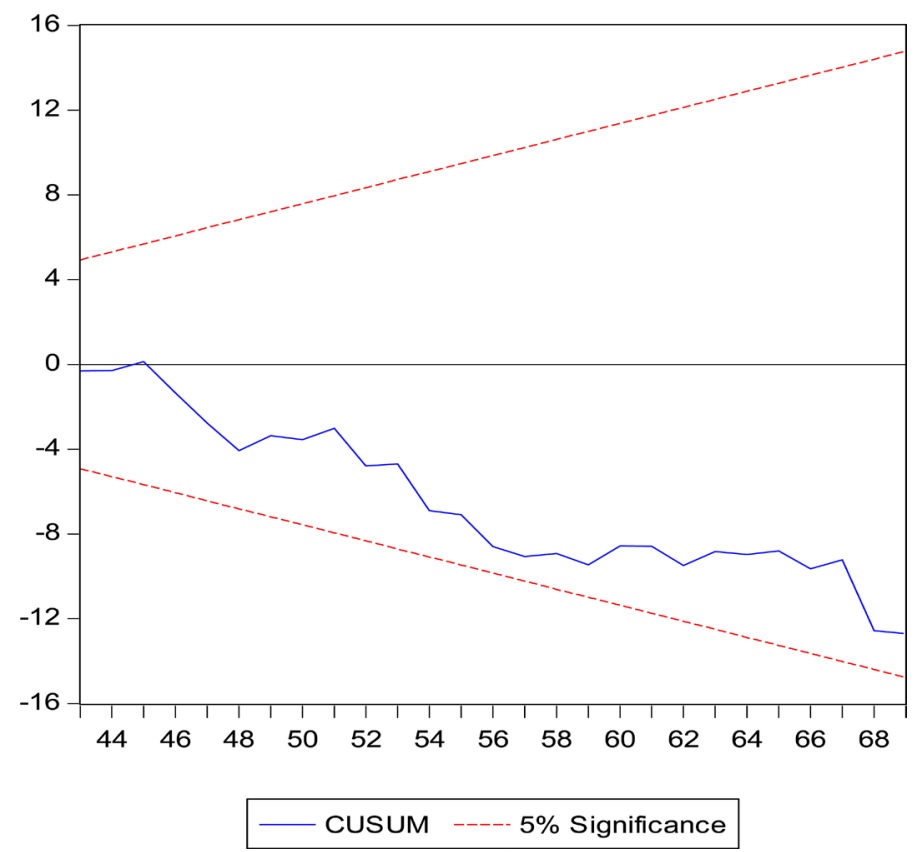

Source: Author's Statistical Output.

Figure 2. CUSUM test. 
two (2) border lines. This indicates that the parameters (i.e. the constant and the individual beta values) of the regression models are stable. This means that the result is more valid.

\subsection{Effect of Board Involvement on Return on Equity}

The effect of board involvement on return on equity has been analyzed using multiple regression models. Individual beta values are provided by Table 5 .

F-test statistics probability is 0.000 . This is highly significant at $1 \%$ level. Therefore, explanatory variables jointly influence on return on equity. As the $\mathrm{P}$-value is highly significant, regression model is appropriate.

According to $\mathrm{R}$ squared, $70.2 \%$ of $\mathrm{ROE}$ has been covered by the regression model. If the value is $60 \%$ or more, it means that the model is nicely fitted; hence, the model is more appropriate.

The rejected hypotheses were 3 and 5 because board's shareholdings and size of the board are both significant at $1 \%$ level. The controlling variable board expertise is also significant at $1 \%$ level.

2.13 is the Durbin Watson test statistics. This is between 1.5 and 2.5. Therefore, it is also saying that residuals are independent and the model is more appropriate.

Table 5. Individual effect of board involvement on return on equity.

\begin{tabular}{|c|c|c|c|c|}
\hline $\begin{array}{l}\text { Dependent Variable: Ret } \\
\text { Method: Least Squares } \\
\text { Sample: } 169 \\
\text { Included observations: } 6\end{array}$ & Equity & & & \\
\hline Variable & Coefficient & Std. Error & $\mathrm{t}$-Statistic & Prob. \\
\hline $\mathrm{C}$ & 0.276 & 0.127 & 2.171 & 0.034 \\
\hline BMF & 0.004 & 0.016 & 0.245 & 0.807 \\
\hline BIC & 0.003 & 0.023 & 0.133 & 0.895 \\
\hline BSH & -0.380 & 0.126 & -3.027 & $(0.004)^{* *}$ \\
\hline BMR & -0.032 & 0.064 & -0.509 & 0.612 \\
\hline BSI & -0.134 & 0.046 & -2.911 & $(0.005)^{\star *}$ \\
\hline FAG & -0.000 & 0.001 & -0.169 & 0.866 \\
\hline BEX & 0.123 & 0.045 & 2.720 & $(0.009)^{\star *}$ \\
\hline FLEV & -0.009 & 0.096 & -0.089 & 0.929 \\
\hline R-squared & 0.702 & \multicolumn{2}{|c|}{ Mean dependent var } & 0.065 \\
\hline Adjusted R-squared & 0.657 & \multicolumn{2}{|c|}{ S.D. dependent var } & 0.329 \\
\hline S.E. of regression & 0.193 & \multicolumn{2}{|c|}{ Akaike info criterion } & -0.323 \\
\hline Sum squared resid & 2.189 & \multicolumn{2}{|c|}{ Schwarz criterion } & 0.001 \\
\hline Log likelihood & 21.148 & \multicolumn{2}{|c|}{ Hannan-Quinn criterion } & -0.195 \\
\hline F-statistic & 15.450 & \multicolumn{2}{|c|}{ Durbin-Watson stat } & 2.132 \\
\hline Prob (F-statistic) & 0.000 & & & \\
\hline
\end{tabular}

Source: Author's Statistical Output. ${ }^{*}$ and ${ }^{*}$ indicate the significance levels at 0.01 and 0.05 respectively. 
The researchers tested the association between explanatory variables and residuals in Table 6. 1.00 is the probability of each independent variable. They are perfectly insignificant. Therefore, residuals are not correlated with independent variables.

\section{Discussions and Conclusions}

This study has identified the impact of board members involvement on ROE. The results of the findings will be discussed in this section. Companies are encouraged to first and foremost consider the shareholdings of directors, the size of the board and the skills of board members in order to achieve performance. The reason is that they are both jointly and individually significant with ROE. Board's shareholdings recorded negative significance on firm performance for ROE. The implication of this is that when directors' shareholdings increase, performance will reduce, and when there is a decline in directors' shareholdings, corporate performance will rise. In addition to the above point, BSH correlates with ROE. It also means that when directors are given more shareholdings, their shareholding power increases and if not well checked, might make them lose focus on their duty to protect the interest of the shareholders by way of being

Table 6. Relationship between residuals and explanatory variables.

\begin{tabular}{cc}
\hline Sample: 169 & \\
Covariance Analysis: Ordinary & \\
\hline & Correlation \\
\hline Probability & $1.59 \mathrm{E}-15$ \\
\hline BMF & 1.00 \\
P value & $-3.27 \mathrm{E}-15$ \\
BIC & 1.00 \\
P value & $1.65 \mathrm{E}-16$ \\
BSH & 1.00 \\
P value & $1.91 \mathrm{E}-16$ \\
BMR & 1.00 \\
P value & $1.28 \mathrm{E}-15$ \\
BSI & 1.00 \\
P value & $6.96 \mathrm{E}-16$ \\
FAG & 1.00 \\
P value & $-2.26 \mathrm{E}-16$ \\
BEX & 1.00 \\
P value & $3.50 \mathrm{E}-15$ \\
FLEV & 1.00 \\
P value & \\
\hline & \\
\hline & \\
\hline &
\end{tabular}

Source: Author's Statistical Output. 
intoxicated by their shareholding power, thereby making them arrogant and insensitive to the affairs that will promote the performance level of the firm. This scenario is in line with a popular adage that says: "Absolute power corrupts absolutely". In a nutshell, this can be the reason why if the board's shareholdings increase, the firm performance will decrease and vice versa (i.e. BSH having negative significant effect). However, firms are advised to have a way of maintaining the directors' shareholdings to the level that it will yield increase in the performance level of the firm. However, with PE, board's shareholding is positively significant at $10 \%$ level [14]. This shows that it is marginally significant.

The analytical results reveal that BSI is negatively significant in relation to ROE at $1 \%$ level, while board size is not significant in relation to PE [14]. ROE has been operationalized with respect to net profit after tax and total equity. Accordingly, BSI is having a significant association with net profit after tax and total equity. Whereas, [28] found out that board size is having negative significant effect with EPS at 5\% level. BSH and BEX are also having a significant association with net profit after tax and total equity.

However, the implications of board size having negative significant effect on performance is that, when board size increases, firm performance will reduce and when board size reduces, corporate performance will increase. This result is consistent with [9] argument, which supported the claim that small board size has influence on firm performance. The finding in the analysis which says that increase in the number of board members will reduce performance level of the company is in line with an old adage which says, "Too many hands in the soup spoil the soup". In other words, it implies that too many board members on board will reduce the corporate performance level of the firms.

Companies that have board of directors with the required expertise and adequate knowledge will do well and also encourage learning, teamwork and effective performance. However, the results reveal that board expertise has positive $1 \%$ level of significant relationship on firm performance with ROE. This indicates that the skills of board members are associated with net profit after tax and total equity. On the other hand, PE records showed that the skills of board members were insignificant [14].

Even though some of the other independent variables and control variables are not individually significant with ROE, they are jointly having effect on ROE. Therefore, it's of paramount importance that those variables should not be taken in isolation; rather they should all be considered jointly in order for them to really have jointly effect on corporate performance.

Furthermore, the researchers of this study found out that the empirical findings revealed in [28] are consistent with the findings in [13] and this current research wherein in [28], the following were the findings: board size is significantly $10 \%$ negative both in EPS and ROE, CEO duality is significantly $10 \%$ positive both in EPS and ROE, firm size is significantly 1\% positive both in EPS and ROE, firm leverage and non-executive directors are both non-significant both in 
EPS and ROE, only in firm age EPS is positively significant at 5\%, while in ROE is non-significant. This was a research about listed companies in the Colombo Stock Exchange. Similar findings like the one above were also revealed in [13] and this current study. Below were the findings of the two (2) studies: directors' shareholdings and board size are both negatively significant at $1 \%$ both in EPS and ROE, board skill is positively significant at $1 \%$ both in EPS and ROE, frequency of board meetings, independent board committees, board members relatives on board, firm age and firm leverage are all non-significant both in EPS and ROE. The above findings have given rise to some questions by the researchers of this study. Such questions are: Are the performance measures EPS and ROE the same? Can EPS and ROE be used interchangeably both in research settings and in the practical world? In order for these questions to be answered with more empirical findings, further research is required whereby; these two (2) performance measures: EPS and ROE should be applied at the same time in a developed economy settings as well as other developing economies. While the researchers of this study await the future findings of the above by other researchers, we are of the opinion that EPS is EPS and ROE is ROE and they cannot be used interchangeably. To further throw more light on this argument, mathematically; $2+2=4$ and $2 \times 2=4$. That both answers are 4 does not mean that addition is the same with multiplication and both can never be used interchangeably. However, "addition" is "addition" and "multiplication" is "multiplication" like in the case of EPS and ROE above.

The applicability of this research findings is not only limited to developing economy. Developed countries are also encouraged to apply the findings where necessary and also when the need arises.

\section{Limitations and Area for Further Research}

During the period of this research, the researchers encountered some limitations. Such limitations are the unavailability of all the required data needed for this study and the study covers one country i.e. Nigeria. For the purpose of future research, it will be beneficial to utilize other measures of performance.

\section{Conflicts of Interest}

The authors declare no conflicts of interest regarding the publication of this paper.

\section{References}

[1] Cadbury Report (1992) The Financial Aspects of Corporate Governance.

[2] Fama, E.F. and Jensen, M.C. (1983) Separation of Ownership and Control. The Journal of Law and Economics, 26, 301-325. https://doi.org/10.1086/467037

[3] Stiles, P. and Taylor, B. (2001) Boards at Work, How Directors View Their Roles and Responsibilities. Oxford University Press, Oxford.

[4] Jensen, M.C. and Meckling, W.H. (1976) Theory of the Firm: Managerial Behavior, 
Agency Cost and Ownership Structure. Journal of Financial Economics, 3, 305-360. https://doi.org/10.1016/0304-405X(76)90026-X

[5] Pfeffer, J. and Salancik, G.R. (1978) The External Control of Organizations: A Resource-Dependence Perspective. Harper \& Row, New York.

[6] Cardon Report (1998) Corporate Governance for Belgian Listed Companies.

[7] Wang, J. and Dewhirst, H.D. (1992) Boards of Directors and Stakeholder Orientation. Journal of Business Ethics, 11, 115-123. https://doi.org/10.1007/BF00872318

[8] Vafeas, N. (1999) Board Meeting Frequency and Firm Performance. Journal of Financial Economics, 53, 113-142. https://doi.org/10.1016/S0304-405X(99)00018-5

[9] Dharmadasa, P., Premarthne, G. and Hearth, S.K. (2014) Corporate Governance, Board Characteristics and Firm Performance: Evidence from Sri Lanka. Journal of Finance and Bank Management, 21, 7-31.

[10] Senaratne, S. and Gunaratne, P.S.M. (2008) Corporate Governance Development in Sri Lanka: Prospects and Problems. International Research Conference on Management and Finance, University of Colombo, Colombo, Sri Lanka, 2008, 79-89. http://archive.cmb.ac.lk:8080/research/handle/70130/1620

[11] Ramdani, D. and Witteloostuijn, A.V. (2010) The Impact of Board Independence and CEO Duality on Firm Performance: A Quantile Regression Analysis for Indonesia, Malaysia, South Korea and Thailand. British Journal of Management, 21, 607-626. https://doi.org/10.1111/j.1467-8551.2010.00708.x

[12] Wijethilake, C., Ekanayake, A. and Perera, S. (2015) Board Involvement in Corporate Performance: Evidence from a Developing Country. Journal of Accounting in Emerging Economies, 5, 250-268. https://doi.org/10.1108/JAEE-12-2012-0050

[13] Nwokwu, T.C., Dharmadasa, P.M.P. and Rathnasingha, P.D.L.M. (2018) Board Involvement on Earnings per Share (EPS): Evidence from a Developing Economy. International Journal for Innovation Education and Research, 6, 130-141. http://www.ijier.net/ijier/article/view/1031

[14] Nwokwu, T.C. (2018) The Influence of Board Involvement on Price Earning: Evidence from Nigeria. International Journal of Recent Advances in Multidisciplinary Research, 5, 3967-3973.

http://www.ijramr.com/issue/influence-board-involvement-price-earning-evidencenigeria

[15] Carver, J. (2010) A Case for Global Governance Theory: Practitioners Avoid It, Academics Narrow It, the World Needs It. Corporate Governance: An International Review, 18, 149-157. https://doi.org/10.1111/j.1467-8683.2010.00785.x

[16] Kesner, I.F. (1988) Directors' Characteristics and Committee Membership: An Investigation of Type, Occupation, Tenure, and Gender. Academy of Management Journal, 31, 66-84.

[17] Ahunwan, B. (2002) Corporate Governance in Nigeria. Journal of Business Ethics, 37, 269-287. https://doi.org/10.1023/A:1015212332653

[18] Anderson, D.W., Melanson, S.J. and Maly, J. (2007) The Evolution of Corporate Governance: Power Redistribution Brings Boards to Life. Corporate Governance: An International Review, 15, 780-797. https://doi.org/10.1111/j.1467-8683.2007.00608.x

[19] Rossouw, G.J., Watt, A. and Malan, D.P. (2002) Corporate Governance in South Africa. Journal of Business Ethic, 37, 289-302. https://doi.org/10.1023/A:1015205511601

[20] Siciliano, J.I. (1996) The Relationship between Formal Planning and Performance in 
Non-Profit Organizations. Nonprofit Management and Leadership, 7, 387-403. https://doi.org/10.1002/nml.4130070405

[21] Achchuthan, S. and Kajananthan, R. (2013) Corporate Governance Practices and Firm Performance: Evidence from Sri Lanka. European Journal of Business and Management, 5, 19-27.

[22] Baccouche, S. (2015) Directors' Multiple Directorships and Their Appointment to Board Committees: Evidence from France. International Review of Management and Business Research, 4, 322-335.

[23] Ehikioya, B. (2009) Corporate Governance Structure and Firm Performance in Developing Economies: Evidence from Nigeria. Emerald Group Publishing Limited, 9 , 231-243. https://doi.org/10.1108/14720700910964307

[24] Coles, J.W., McWilliams, V.B. and Sen, N. (2001) An Examination of the Relationship of Governance Mechanisms to Performance. Journal of Management, 27, 23-50. https://doi.org/10.1177/014920630102700102

[25] Chen, K.D. and Wu, A. (2016) The Structure of Board Committees. Harvard Business School, Working Paper 17-032, 1-37.

https://www.hbs.edu/faculty/Publication\%20Files/17-032_22ea9e7a-4f26-4645-af3d $-042 \mathrm{f} 2 \mathrm{~b} 4 \mathrm{e} 058 \mathrm{c} . \mathrm{pdf}$

[26] Ruigrok, W., Peck, S.I. and Keller, H. (2006) Board Characteristics and Involvementin Strategic Decision Making: Evidence from Swiss Companies. Journal of Management Studies, 43, 1201-1226. https://doi.org/10.1111/j.1467-6486.2006.00634.x

[27] Carpenter, M. and Westphal, J. (2001) The Strategic Context of External Network ties: Examining the Impact of Director Appointments on Board Involvement in Strategic Decision Making. Academy of Management Journal, 4, 639-660.

[28] Azeez, A.A. (2015) Corporate Governance and Firm Performance: Evidence from Sri Lanka. Journal of Finance and Bank Management, 3, 180-189. https://doi.org/10.15640/jfbm.v3n1a16

[29] Iyengar, R.J. and Zampelli, E.M. (2009) Self-Selection, Endogeneity, and the Relationship between CEO Duality and Firm Performance. Strategic Management Journal, 30, 1092-1112. https://doi.org/10.1002/smj.776

[30] Matta, E. and Beamish, P.W. (2008) The Accentuated CEO Career Horizon Problem: Evidence from International Acquisitions. Strategic Management Journal, 29, 683-700. https://doi.org/10.1002/smj.680

[31] Bill, G. (2019) 12 Key Financial Performance Indicators You Should Be Tracking. https://www.accountingdepartment.com/blog/12-key-performance-indicators-youshould-be-tracking 